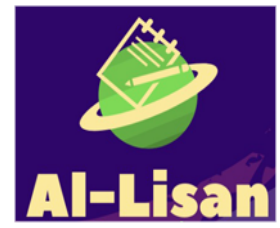

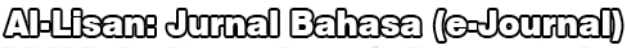

Lilli sultell lillet celchite

Volume 5, Nomor 2, Agustus 2020

ISSN 2442-8965 (P) ISSN 2442-8973 (E)

\title{
Naturalness of Translation in J. K. Rowling's Novel Harry Potter and the Half Blood Prince into Indonesian
}

\author{
Siti Aisyah \& Dwi Harjanti \\ buaisy12@gmail.com \& dwi.harjanti@ums.ac.id \\ Universitas Muhammadiyah Surakarta, Indonesia
}

\begin{abstract}
A good quality of translation is known by assessing it. One way to assess translation product is by assessing the naturalness. This research aims at describing the naturalness of translation in J. K. Rowling's Harry Potter and the Half Blood Prince novel into Indonesian version Harry Potter dan Pangeran Berdarah Campuran. This is a descriptive qualitative research. The data were sentences in the original novel and its Indonesian translation. The data were collected using content analysis technique and analyzed using Larson theory of naturalness in translation and supported by other theories. This research does not mean to judge the translator but it is intended to give contribution to the development of translation by analyzing the naturalness of the translation. The finding showed that there are four levels of naturalness found in the translation of the novel, such as (1) highly natural (171 data or 78.1\%), (2) natural (33 data or $15.1 \%)$, (3) less natural (13 data or $5.9 \%$ ), and (4) unnatural (2 data or $0.9 \%)$.
\end{abstract}

Keywords: Naturalness; Translation Quality; Novel.

\section{A. INTRODUCTION}

Translation takes an important role in learning foreign language. It deals with transferring the writer's idea from source language into target language (Newmark, 1987). House (2018: 9), Catford (1965: 20), and Larson (1998) state almost similar definition about translation that it refers to seeking for the equivalence between the source text and the target text. The equivalence should be semantically and pragmatically. Jacobson (1959/2004: 139 in Munday, 2008: 5) stated that translation refers to several definitions, namely translation as a general subject field, as a product, and as a process. Translation as a subject field refers to teaching and learning of translation in the academic field. Translation as a product refers to the text that has been translated into the target language. Translation as a process means the act of producing 
the translation (ibid). It means that translation centralizes on the role of the translator in picking the source text (ST) and transforming it into a text in target language (Suttleworth and Cowie, 1997: 181 in Hatim and Munday, 2004).

In translating a text, the translator should take some considerations to make the result of the translation has a good quality. The considerations are related to the culture (especially the source language), syntactical terms, and the message of the text. Besides, the other important things that should be paid attention by translator such as: first, the process of translation. It deals with the source text reading, target text writing, and the process itself (Schaeffer and Carl, 2015). The translator first reads the source text, and then produces the target text through a process. Nababan (2008: 25) mentions three steps in translation process, namely: (1) analyzing the source text where the translator reads the original text and comprehends the message; (2) transferring the message in which the translator transfers the content and the message of the original text to the target text (it is still in the translator mind); and (3) re-structuring in which the translator changes the original text into the target text by considering to find the equal message between the source language and the target language. Larson (1998: 3-4) states that translation process consists of studying the lexicon, grammatical structure, communication situation, and cultural context of the source text; determining the meaning by analyzing it; and then reconstructing this same meaning using lexicon and grammatical structure which are appropriate in a receptor language and its cultural context. Here is the process of translation according to Larson (1998):

Chart 1. The Process of Translating

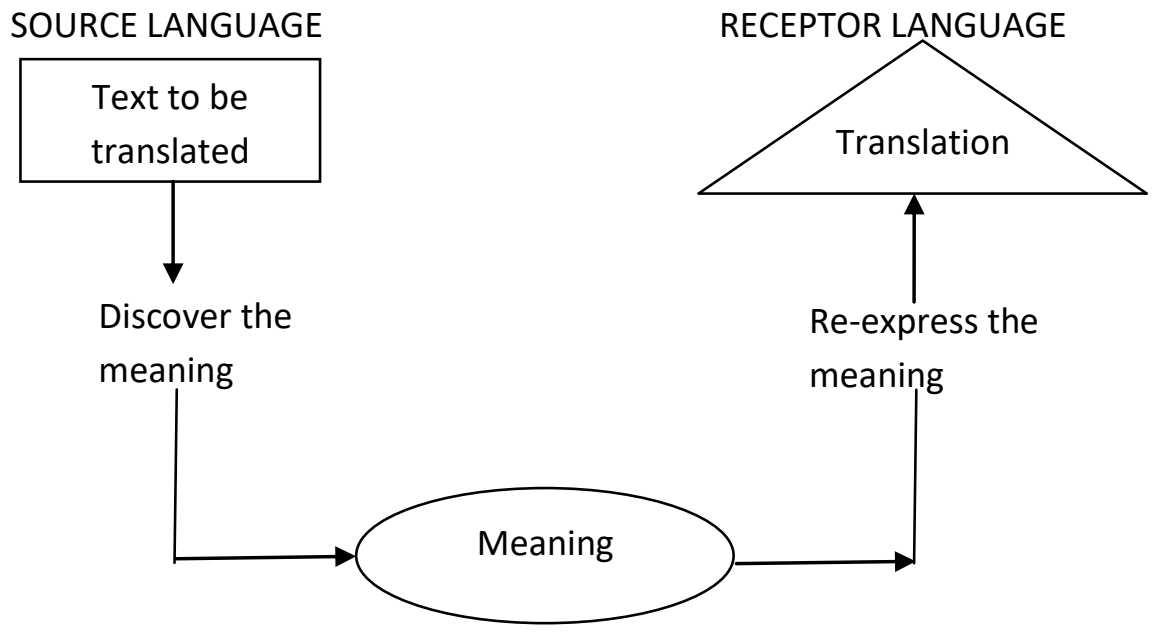


Second, the procedure of translation. Nida (1964 in Ordudari) mentions two kinds of translation procedure, such as (1) technical procedures which cover analyzing both the source and target languages; studying the source language text before translate it; and making judgments of semantic and syntactic approximation; (2) organizational procedures which contain some activities like constant reevaluation of the attempt made; contrasting the translation with the existing translation of the same text done by other translators; and checking the text's communicative effectiveness by asking the target language readers to evaluate the accuracy and effectiveness and to know their reactions.

Third, techniques of translation. In order to make the translation product of the target text equivalent with the source text, the translator does some techniques. Mona and Albir (2002: 509 in Rahmawati, Nababan, \& Santosa, 20016) mention some techniques in translation such as adaptation, amplification, borrowing, calques, compensation, description, discursive creation, established equivalence, generalization, linguistics amplification, linguistic comprehension, literal translation, modulation, particularization, reduction, substitution, transposition, and variation.

The quality of translation can be identified through some assessments. According to Larson (1998: 529), the aim of assessing translation is to ensure that it is accurate, clear, and natural. He (1998: 533) explains ways of assessing translation such as: (1) comparison with the source to check whether or not the information content in TL equivalence with the SL; (2) back-translation into the source language which is done by asking someone else who masters the source and the target language well to read the translation and write the meaning he gets from it back into the source language again; (3) comprehension checks to know whether or not the speakers of the TL understand it correctly although they do not read it before; (4) naturalness and readability testing is to know if the form of the translation is natural and the style appropriate; and (5) consistency checks to check the consistency of the use of lexical equivalent for some key terms.

The kinds of assessment can be applied to any kinds of translation. One of a very interesting field of translation is literary work such as, novel, film, poetry, and short story. Related to the background of the study above, this research is going to discuss the 
translation quality assessment which is focused on the naturalness quality. It will analyze the naturalness of translation of a very famous novel by J. K. Rowling entitle "Harry Potter and the Half Blood Prince" which has been translated into Indonesian "Harry Potter dan Pangeran Berdarah Campuran". This novel has been translated into many languages and spread to all over the world. Not only children who like this novel, but also young people and the older ones. The acceptance of many people to this novel make it become interesting object to study, especially about its naturalness quality.

There are some researches about naturalness, among others are: first, Baharuddin (2015) conducted a research investigating the naturalness of the Indonesian language used by the translator in the translation of Anna Frank's The Diary of a Young Girl into Indonesian. The result of the research was that there are two things caused the translation unnatural in the text; they are the text structure and the meaning and sense. Second, Dewi et.al (2015) analyzed the naturalness of translation of short story Drupadi from Indonesian into English. They found that the translation has a highly natural quality, so that it can be used as a teaching material in language classes. Third, Safei and Salija (2018) analyzed the naturalness and accuracy of English short story translation into Indonesian. The research showed that the students' translation of short story entitled The Proud Lion gained the score 7-8. It is called 'almost completely successful' classification from 30 students.

This study differs from the above previous studies. The differences are in the focus being studied and the subject. This study is focused on naturalness of the translation of J. K. Rowling's Harry Potter and the Half Blood into Indonesian Harry Potter dan Pangeran Berdarah Campuran. The problem to be discussed is how the naturalness quality of the translation is. By this research, it is expected that it will become reference to other researchers who are interested in translation and its development. It can give the illustration on how translator should translate the literary work by considering the naturalness of the translation product in order to make the readers understand it easily.

In literary translation, naturalness becomes urgent to gain the equivalence meaning between source language and target language. Newmark (1988: 24, 26 in Safi and Syarifi, 1997) states that translation is natural when it uses common structure or 
grammar, idioms and words that meets the situation. There are two features of naturalness in translation (ibid). They are primary feature (intelligibility and accessibility / readability); and secondary feature (well-formedness, acceptability, idiomaticity, authenticity and contemporaneity). Intelligibility means the clarity of the translation that makes the readers comprehend it easily (Yusof, Aziz, \& Darus, 2017). Accessibility or readability refers to the clarity of the translation due to the style of writing (Klare, 1963 in Ghoreishi \& Aminzadeh, 2016). Well-formedness relates to the consistency of the translation to the TL grammar rules without any interference from the SL syntactic rules. Acceptability is the appropriateness of the translation with the TL linguistic and cultural norm. Idiomaticity is the inclination of using certain established formulas in the TL culture like proverbs, idioms and collocation. Authenticity means that the translation is free from linguistic and cultural interferences of SL. Contemporaneity characterized by the use of contemporary words instead of archaic ones (Yusof, Aziz, \& Darus, 2017).

Naturalness test is done to know if the form of the translation is natural and the style appropriate. It can be done by asking a reviewer to read it, making comments and giving suggestions. It will be better if the reviewer is one who is bilinguals in source language and target language. The first step done by reviewer is by reading the whole section of the translation at one time. The purpose of this step is to know the flow of the translation, and the whole meaning of the text. While reading, the reviewer mark any place where it is hard to read or it looks unnatural or unclear. If he feels hesitated and has to go back, and reread to understand, this should be marked. After finishing reading the translation, then he should go back and study carefully to the marker he makes. Then he can write some additional suggestions on it (Larson, 1998: 533-544). Then the reviewer can make some criteria to assess the naturalness of the translation. The following table is the criteria in assessing translation (Dewi, et.al, 2015 adapted from Larson, 1988: 531-532): 
Table 1. Criteria in assessing naturalness

\begin{tabular}{ccl}
\hline Scale & Level & \multicolumn{1}{c}{ Criteria } \\
\hline 4 & Highly & Make sense and read naturally (written in ordinary \\
natural & language, common grammar, proper idioms and words) \\
3 & Natural & $\begin{array}{l}\text { Correct meaning, using appropriate idioms and words, } \\
\text { but there are some error structures. }\end{array}$ \\
2 & Less natural & $\begin{array}{l}\text { Make sense with minimum unnatural words, grammar, } \\
\text { phrase, or idioms. } \\
\end{array}$ \\
& Unnatural & Unnatural form, with awkward language, \\
& & ungrammatical structure, and inappropriate words.
\end{tabular}

\section{B. RESEARCH METHOD}

This study is descriptive qualitative research. Qualitative research refers to a research which study how people deal with 'their concrete real-life experiences in their own minds and in their own words' (Cropley, 2019). It does not use statistical procedure as in quantitative research. One of the characteristics of qualitative research is the data are in the form of sentences and analyzed descriptively. The data in this research are in the form of sentences in the source text Harry Potter and the Half Blood Prince and its Indonesian translation. Harry Potter's novel was chosen because it is very popular and has been translated into many languages. Thus, it is very interesting to analyze the extent of the naturalness of the translation that make the readers of any ages understand it easily and then love it. The data are collected by using documentation technique. The authors read the sentences in the source text and choose the corpus language. Next, the authors compare them to the Indonesian translation and analyzed descriptively by using the theory of naturalness.

\section{FINDINGS AND DISCUSSION}

\section{Findings}

There are 219 data the writer used taken from the novel. This research found that the naturalness level of the translation can be categorized as highly natural (171 data or $78.1 \%$ ), natural (33 data or $15.1 \%$ ), less natural (13 data or $5.9 \%$ ) and unnatural (2 data or $0.9 \%)$. The translation is called having highly natural quality if it makes sense 
and read naturally or written in ordinary language, common grammar, proper idioms and words. Translation is categorized as natural if it has correct meaning, using appropriate idioms and words, but there are some error structures. Translation is called less natural if it makes sense with minimum unnatural words, grammar, phrase, or idioms. Meanwhile, translation is called unnatural if it has unnatural form, with awkward language, ungrammatical structure, and inappropriate words. Here are the explanations of some data:

1. Unnatural level

Translation is categorized as unnatural if it has unnatural form, with awkward language, ungrammatical structure, and inappropriate words. The data showed that there are 2 unnatural translations which occur in the novel. Here they are:

ST: And was it his fault that one of his Junior Ministers, Herbert Chorley, had chosen this week to act so peculiarly that he was now going to be pending a lot more time with his family? (p. 8)

TT: Dan salahnyakah jika salah satu menteri mudanya, Herbert Chorley, telah memilih minggu ini untuk bersikap begitu ganjil sehingga sekarang dia akan melewatkan jauh lebih banyak waktu bersama keluarganya? (p. 10)

As stated by Larson, translation is called natural if it is easy to read and not hard to understand. Meanwhile in this data, the translation is hard to understand especially in the sentence "telah memilih minggu ini untuk bersikap begitu ganjil sehingga dia melewatkan jauh lebih banyak waktu bersama keluarganya”. There is an ambiguity reference of the pronoun "dia". Does it refer to the Prime Minister or to the Junior Minister, Herbert Chorley? It is unclear and makes the sentence unnatural. Related to the naturalness of translation, Tytler (1907: 9 in Roger, 1999) and Nida (1964: 164 in ibid) states that translation should have natural and easy form of expression, so that it is read like the original text and not like a translation. The above translation is still using awkward language and still like a translation. In natural translation, translator is free to add or retrench the original text if it is needed in order to make it ease to comprehend (Tytler, 1779 in Fadaee, 2011). In this translation, there is no addition or reduction to make it more natural and easily understand.

ST: "Good grief, so it's your fault those people were killed and I'm having to answer questions about rusted rigging and corroded expansion joints and I don't know what else!" said the Prime Minister furiously. (p. 21)

TT: "Astaga, jadi kesalahan Anda-lah orang-orang ini terbunuh dan saya harus menjawab pertanyaan-pertanyaan tentang tiang penyangga berkarat dan 
perpanjangan-sendi keropos dan entah apa lagi!" kata Perdana Menteri (p.23)

In this data, the translator translates the sentence corroded expansion joints into perpanjangan-sendi keropos. In target language the translation is difficult to understand and seems strange. It has no intelligibility based on Newmarks criteria of natural translation. The translation does not make the readers comprehend it easily. It sound unnatural and make the readers should think twice to understand.

\section{Less Natural Level}

Translation belongs to less natural if it makes sense with minimum unnatural word, grammar, phrase, or idioms. There are 13 data or $5.9 \%$ categorized as having less natural quality. Here are the examples:

ST: ..., it was to find Hermione sitting at the kitchen table in great agitation, while Mrs Weasley tried to lessen her remembrance to half a panda. (p.123)

TT: ..., Hermione sedang duduk di kursi meja makan dengan sangat gelisah, sementara Mrs Weasley berusaha mengurangi kemiripannya dengan separo-panda. (p.131)

The data show that a phrase in the source text 'half a panda' is translated literally correct to 'separo panda', but it belongs to less natural because it is uncommon phrase. The readers will be difficult to understand what 'separo panda' mean because this phrase is not ordinary use in target language. There is no panda which is only separo (a half), so it will make the readers confuse. Although the word separo panda is uncommon, but actually if the translator does not use the word separo, the readers will more understand, so it belongs to less natural translation.

ST: Harry followed his gaze up the carefully tended front path and felt his heart sink. The front door was hanging off its hinges. (p.79)

TT: Harry mengikuti pandangannya melewati jalan setapak dan hatinya mencelos. Pintu depan menggantung pada engselnya. (p.86)

The translation belongs to less natural because it uses unnatural words. In this example, the target word mencelos is rarely used in daily conversation, so it can be categorized as unnatural word. It does not make the readers understand. This word is an archaic word, as stated by Newman that if translation use archaic words, so it is less natural. 


\section{Natural Level}

Translation is categorized as natural if it has correct meaning, using appropriate idioms and words, but there are some error structures. There 33 data or $15.1 \%$ which are categorized as having natural quality of translation. The natural translation will be identified from the meaning which is equivalent, the appropriate idioms and common words. However, there is a small mistake related to the sentence structure, for example:

ST: An immense chimney, relic of a disused mill, reared up, shadowy and ominous (p.29)

TT: Sebuah cerobong besar, peninggalan penggilingan yang sudah tak terpakai, menjulang, seperti bayangan yang mengerikan (p.32).

This translation can be said as having natural level because almost all the words are common words. The meaning of the translation are closest to the original text, however there is one word which make it strange, the word relic is translated into peninggalan, in which combined with the word penggilingan that need more than once to read in order to get the meaning. It is only a small mistake related to the structure of the sentence.

ST: Fudge took a great, deep breath and said, "Prime Minister, I am very sorry to have to tell you that he's back. He-Who-Must-Not-Be-Named is back." (p.19)

TT: Fudge menarik napas dalam-dalam dan berkata, "Perdana Menteri, saya sungguh menyesal terpaksa harus memberitahu Anda bahwa Dia yang Namanya Tak Boleh Disebut telah kembali." (p.21)

In this data, the meaning of the source text and the target text is closest; however there is a difference structure between the two texts. In the source text there are two direct speeches using two words 'back', but in the target language the direct speech is only one sentence with one 'kembali'. Although there is no strangeness in this translation and it can be understand easily or called natural, but there occurs a different structure between two sentences.

4. Highly Natural Level

Translation is called having highly natural quality if it makes sense and read naturally or written in ordinary language, common grammar, proper idioms and words. There are 171 data or $78.1 \%$ belong to highly natural translation. It can be said that more than a half data show that the translation is natural. The readers will read and understand it easily as if it is the original text. Here are the examples: 
ST: 'I'm not getting rid of Kingsley Shacklebolt, if that's what you're suggesting!" said the Prime Minister hotly. (p. 27)

TT: "Saya tidak bersedia memberhentikan Kingsley Shackebolt, kalau itu yang akan Anda usulkan!” kata Perdana Menteri panas. (p.29)

The data above show that the translation uses ordinary language. It can be understood easily. It also uses common grammar, correct use of capital letter and punctuation. The words used are not awkward. This translation can be categorized as having high level of naturalness. The all result of the findings is summarized as in the following table:

Table 2: The Naturalness of Translation in the Novel

\begin{tabular}{ccc}
\hline Level & Data & Percentage \\
\hline Unnatural & 2 & $0.9 \%$ \\
Less Natural & 13 & $5.9 \%$ \\
Natural & 33 & $15.1 \%$ \\
Highly Natural & 171 & $78.1 \%$ \\
\hline Total data & & \\
\hline
\end{tabular}

\section{Discussion}

A major character in every translation work is the translation (final product) should be sounded natural. Before stating the features of the product the naturalness of translation proposed by the great translation authorities, and then mention the types of translations Unnatural translations, a distinction must be made between natural language, ordinary language, and basic language. "Natural language is a language which readable by everyone and it is formal. Ordinary language is a plain, non-technical language used by Oxford. Philosopher's explanation. Basic language is somewhere between formal and informal, easily understood, and it's made of the languages that are the most common people are frequently used" (Newmark, 1988:87).

According to Belloc (1931: 30), "Natural and good translation must consciously attempt the original spirit at the letter's expense. This is much like saying that the translator needs to be original talent; he has to create himself: he has to have his own power, not just to offer a one to one translation". Bates (1943: 121) says that; "If you want to translate a book naturally, you should know that, the translator's task is not 
confined to transferring of one sentence into a similar sentence in the target language, but that he/she is expected to search inconsistencies in the two languages, tackle them, and to overcome the deficiencies of his/her own language in respect of the unique characteristics found in the source language".

The final translation of the two novels of J. K. Rowling's Novel Harry Potter and the Half Blood Prince into Indonesian showed that the translator provided highly naturalness with $78.1 \%$ of the whole translation. It means that the translator success to make the text readable, understood what kind of audience the original author had in mind when writing (Nida, 1943), made readers do not recognize it as translation at all (Rahimi, 2004), and used communicative translation more than semantic translation (Newmark, 1988).

\section{CONCLUSIONS}

Translation relates to the transfer of messages from source language to equivalent messages in target text. Translation is done through some process to get a good result and quality. Some method take by translator in the process of translation will give impact to the better translation. To know the quality of translation, some assessment can be done in a study. One example is by assessing the naturalness quality of the translation product. There are four levels of translation found, such as: highly natural, natural, less natural and unnatural level. By this study, it is hoped that other researchers can used it as reference in their research in field of translation. Some quality of translation which is needed to analyzed such accuracy, readability and acceptability. 


\section{REFERENCES}

Baharudin. (2015). Naturalness in Translation of English Novel into Indonesian. Proceedings of the International Seminar Language Maintenance and Shift V, September 2-. Semarang: Diponegoro University.

Bates E.,S (1943). Intertrafic: Studies in Translation. London: J. Cape Publication.

Belloc H (1931). On Translation, Oxford: Oxford University Press.

Catford, J.C. (1965). Language and Language Learning: A Linguistic Theory of Translation. Edinburg: Oxford University.

Cropley, A. J. (2019). Qualitative Research Methods: A Practice-oriented Introduction for students of psychology and education. Riga, Latvia: Zinatne. (open accessdoi: 10.13140/RG.2.1.3095.6888).

Dewi, N.L.V.P, Mardjohan, A \& Santosa, M. H. (2015). The Naturalness of Translation in Translating Short Story Entitled 'Drupadi' from Indonesian into English. EJournal vol.XI. Singaraja: Universitas Pendidikan Ganesha.

Fadaee, E. (2011). Translation Naturalness in Literary Works: English to Persian. International Journal of English and Literature, vol 2(9), page 200-209 retrieved from http://www.academicjournals.org/ijel DOI: 10.5897/IJEL11.089.

Hatim, B. \& Munday, J. (2004: 26). Translation: An Advanced. New York: Routledge.

House, J. (2018). Translation: the Basics. London: Routledge.

Larson, M. L. (1998). Meaning Based Translation: A Guide to Cross Language Equivalence. Boston: University Press of America.

Munday, J. (2008). Introducing Translation Studies: Theories and Application. New York: Routledge.

Nababan, M. R. (2008). Teori Menerjemah Bahasa Inggris. Yogyakarta: Pustaka Pelajar.

Newmark, Eugene, A \& Taber. (1987). A Text Book of Translation. Great Britain: Prentice Hall.

Newmark., P. (1988). A Textbook of Translation, New York: Prentice Hal.

Nida E., A (1943). Towards a Science of Translation, with Special Reference to Principles and Procedures Involved in Bible Translating. Leiden, the Netherlands: E. J. Brill, for the United Bible. 
Ordudari, M. (2007). Translation Procedures, Strategies and methods. Translation journal Vol. 11. No. 3, 2007. https://translationjournal.net/journal/41culture.htm.

Rahimi R (2004). "Alpha, Beta and Gamma Features in Translation: Towards the Objectivity of Testing Translation". Translation Studies, 2(5).

Rahmawati, A.Y, Nababan, M. R \& Santosa, R. (2016). “Kajian Teknik Penerjemahan dan Kualitas Terjemahan Ungkapan yang Mengandung Seksisme dalam Novel the Mistress's Revenge dan Novel The $19^{\text {th }}$ Wife" in Prasasti: Journal of Linguistics, vol. 1, number 2 November.

Rogers, M. (1999). Naturalness and Translation. In Rasmussen, Willy, Roald, Jan \& Simonnaes, Ingrid (eds). SYNAPS 2. Bergen: NHH 9-31.

Rowling, J. K. (2005). Harry Potter and the Half-Blood Prince. London: Bloomsbury.

(2006). Harry Potter dan Pangeran Berdarah Campuran (alih bahasa, Listiana Srisanti). Jakarta: Gramedia Pustaka Utama (Original work published 2005).

Safei, N. H \& Salija, K. (2018). The Naturalness and Accuracy of English Short Story Translation into Indonesian. Universitas Negeri Makasar: ELT Worldwide Vol 5 No 1.

Schaefer, M \& Carl, M. (2013). Shared Representation and the Translation Process: A Recursive Model. John Benjamin Publishing Company, retrieved from https://www.researchgate.net/publication/300466631.

Yusof, N. M, Aziz, M. N \& Darus, S. (2017). Evaluating Intelligibility in Human Translation and Machine Translation. The Southeast Asian Journal of English Language Studies-Vol. 23(4): 251-264. Retrieved from http://doi.org/10.17576/3L-2017-2304-19. 